\title{
The role of Wnt signaling in neuronal dysfunction in Alzheimer's
}

\section{Disease}

\author{
Nibaldo C Inestrosa*1,2 and Enrique M Toledo ${ }^{1}$
}

Address: ${ }^{1}$ Centro de Envejecimiento y Regeneración (CARE), Centro de Regulación Celular y Patología "Joaquín V. Luco" (CRCP), MIFAB, Facultad de Ciencias Biológicas, Pontificia Universidad Católica de Chile, Alameda 340, Santiago, Chile and ${ }^{2}$ CARE \& CRCP Biomedical Center, Faculty of Biological Sciences, P. Catholic University of Chile, P.O. Box 114-D, Santiago, Chile

Email: Nibaldo C Inestrosa* - ninestrosa@bio.puc.cl; Enrique M Toledo - etoledo@bio.puc.cl

* Corresponding author

Published: 24 July 2008

Molecular Neurodegeneration 2008, 3:9 doi:10.1186/1750-1326-3-9
Received: 6 June 2008

Accepted: 24 July 2008

This article is available from: http://www.molecularneurodegeneration.com/content/3/1/9

(C) 2008 Inestrosa and Toledo; licensee BioMed Central Ltd.

This is an Open Access article distributed under the terms of the Creative Commons Attribution License (http://creativecommons.org/licenses/by/2.0), which permits unrestricted use, distribution, and reproduction in any medium, provided the original work is properly cited.

\begin{abstract}
Recent evidence supports a neuroprotective role for Wnt signaling in neurodegenerative disorders such as Alzheimer's Disease (AD). In fact, a relationship between amyloid- $\beta$-peptide $(A \beta)$-induced neurotoxicity and a decrease in the cytoplasmic levels of $\beta$-catenin has been observed. Apparently $A \beta$ binds to the extracellular cysteine-rich domain of the Frizzled receptor $(\mathrm{Fz})$ inhibiting Wnt/ $\beta$ catenin signaling. Cross-talk with other signaling cascades that regulate $W n t / \beta$-catenin signaling, including the activation of $M_{1}$ muscarinic receptor and PKC, the use of Ibuprofen-ChE bi-functional compounds, PPAR $\alpha, \gamma$ agonists, nicotine and some antioxidants, results in neuroprotection against $A \beta$. These studies indicate that a sustained loss of Wnt signaling function may be involved in the $A \beta-$ dependent neurodegeneration observed in Alzheimer's brain. In conclusion the activation of the Wnt signaling pathway could be proposed as a therapeutic target for the treatment of AD.
\end{abstract}

\section{Introduction}

Alzheimer's disease (AD) is a neurodegenerative disorder associated with aging and characterized by fibrillar deposits of $\mathrm{A} \beta$ in subcortical brain regions. Typical features of $\mathrm{AD}$ are extracellular neuritic amyloid plaques (senile plaques) and intracellular neurofibrillary tangles. The main proteinaceous component of the amyloid deposited in $\mathrm{AD}$ is the $\mathrm{A} \beta$ peptide, a 40-to 42-residue peptide that has been isolated from senile plaque cores. Studies in $\mathrm{AD}$ mouse models and $\mathrm{AD}$ patients support the hypothesis that $\mathrm{A} \beta$ causes "synaptic failure" before plaques develop and neuronal cell death occurs; such effects are produced by $A \beta$ oligomers, which are soluble and toxic molecular forms of $A \beta[1]$.

The importance of Wnt (wingless-type murine-mammarytumour virus integration site) signaling in many adult and developmental processes, such as gastrulation, axis formation, cell polarity, organ development and maintenance of stem cell pluripotency, is widely acknowledged $[2,3]$. In embryos, signaling by Wnt factors controls the organization of the body plan during the early stages of development as well as organogenesis at later developmental stages. Postnatally, Wnt signaling is involved in normal biological events such as tissue maturation and homeostasis and in several neoplastic pathologies. In the mammalian central nervous system (CNS), Wnt signal transduction is involved in neural induction and patterning in early embryogenesis; previous studies have also linked Wnt signaling to neurodegenerative disorders such as $\mathrm{AD}$ [4-6]. In fact, strong evidence suggests that a loss of Wnt function is implicated in the pathophysiology of neuronal degeneration of AD. Wht signaling is complex; 19 mammalian Wnt genes have been cloned, and more than 
ten membrane receptors and a plethora of cofactors and regulators are known. Different mechanisms of Wnt signaling have also been identified. The best understood of these is the "canonical" pathway, in which $\beta$-catenin transduces the Wnt signal to the nucleus [7]. In this case, the signaling cascade by Wnts involves an interaction with a receptor complex comprising members of the Frizzled (Fz) class of 7-transmembrane receptors and a member of the low density lipoprotein receptor 5/6 (LRP 5/6) family of single-pass membrane proteins. Wnt interaction with its receptor results in an increase in the stability of $\beta$-catenin, whose accumulation results in translocation to the nucleus where it can interact with members of the TCF/ LEF class of transcription factors and therefore modulate gene expression. The stability of $\beta$-catenin is controlled by Wnt through the modulation of a large cytoplasmic protein complex comprised of the protein Axin (axis inhibition protein), APC (adenomatosis polyposis coli), CK1 $\alpha$ (casein kinase 1 alpha), GSK-3 $\beta$ (glycogen synthase kinase 3 beta) and G $\beta P /$ frat [8]. GSK-3 $\beta$ directly controls the level of $\beta$-catenin phosphorylation, which leads to its consequent degradation by the proteasome pathway [9]. Wnt signaling is regulated by a wide range of proteins, which act either intracellularly by affecting signal transduction, or extracellularly by interfering with the interaction between Wnt ligands and their membrane co-receptors [10]. Different families of extracellular antagonists of the canonical Wnt pathway have been described, such as Wise, the secreted frizzled-related protein (sFRP), the Wnt inhibitory factor 1 (Wif1), Cerberus, and the Dickkopf (Dkk) family of secreted proteins. Of the four known Dkk family members, Dkk-1 is uniquely described as a negative modulator of the canonical Wnt signaling, whereas, Dkk-2 for example may activate or inhibit the pathway depending on the cellular context. Dkk-1 is expressed at very low levels in the adult brain [11], and binds to LRP $5 / 6$ and the transmembrane protein Kremen-2, promoting the endocytosis and subsequent degradation of LRP 5/ 6 , which is no longer available as a co-receptor for Wnt [12].

Little is known about the role of the heparan sulfate proteoglycans (HSPGs) in vertebrate Wnt signaling [13]. A comparable signaling system, however, may help to elucidate its involvement. Genetic evidence demonstrates that two Drosophila genes involved in $\mathrm{Wg}$ signaling, dally (division abnormally delayed) and $d l p$ (dally-like), reveal a predicted protein sequence that resembles the protein cores of glypican (HSPG) [14-16]. Flies homozygous for hypomorphic dally alleles exhibit some wing-margin defects, a phenotype similar to partial loss of $\mathrm{Wg}$ activity [14]. Dally's sensitivity to heparin lyase II and not to chondroitinase $\mathrm{ABC}$ treatments indicates that it contains heparan sulfate chains [16]. With this understanding, for studying the involvement of HSPG in Neuro2a cells and hippocampal neuron signaling, we used heparin as a glycosaminoglycan (GAG) model to investigate the modulation of $\beta$-catenin. We found that heparin modulates the levels of cytoplasmic $\beta$-catenin in a concentrationdependent manner in Neuro2a cells. Mainly HS residues are involved, since other GAGs, such as chondrotin (CS) or dermatan sulfate (DS), had little effect. The effect of heparin involves a decrease in the activity of GSK-3 $\beta$ and phosphorylation of its Ser 9 residue complemented with the increase of $\beta$-catenin. These results are consistent with the idea that increases in $\beta$-catenin levels are the result of an inhibition of GSK-3 $\beta$ activity, particularly through phosphorylation of the Ser 9 residue. In addition, heparin affects $\beta$-catenin and GSK-3 $\beta$ activity in rat hippocampal neurons, and Wnt-3a modulates the effect of heparin on $\beta$-catenin levels [17]. More importantly, the presence of heparin enhances the protective effect of Wnt-3a against $\beta$-amyloid neurotoxicity (Table 1 ).

Historically, Wnt proteins were classified as either canonical, such as Wnt-1 and Wnt-3a, or non-canonical, including Wnt-4, Wnt-5 and Wnt-11 [7,18,19]. The characterization of Fz, LRPs and other receptor function has challenged this classification of individual Wnt proteins. Evidence suggests that Wnt-5a, for example, may activate the canonical pathway or inhibit it, depending on the receptor involved [20]. Accordingly, the terms "canonical" and "non-canonical" are used to indicate molecular mechanisms, not specific Wnt proteins. Two non-canonical Wnt pathways have been described to play a role in development: (i) the planar cell polarity (PCP) pathway, in which $\mathrm{Fz}$ acts through Jun N-terminal kinase (JNK) to regulate the cytoskeleton, and (ii) the Wnt-Ca ${ }^{2+}$ signaling pathway, in which Fz activation leads to increased intracellular $\mathrm{Ca}^{2+}$ and nuclear import of the transcription factor NFAT [21]. These show that not only are alternative Wnt pathways utilized to specify pattern formation during development, but also different mechanisms. Although the final output of the canonical and the non-canonical Wnt- $\mathrm{Ca}^{2+}$ pathways are the regulation of gene expression, the PCP pathway controls planar cell polarity by modulating the cytoskeleton $[22,23]$.

At the beginning of this decade (Early in 2000), we found a relationship between a loss of the Wnt signaling pathway activity and AD. Early studies in our laboratory suggested a relationship between $A \beta$-induced neurotoxicity and an impairment of this signaling pathway, Figure 1[4,24-26]. Several independent studies are consistent with the idea that Wnt signaling components are altered in $\mathrm{AD}$ [27-33]. As a result, we have studied whether or not the activation of the Wnt signaling pathway may be used as a therapeutic strategy to treat AD. 
Table I: Heparin Modulation of the Wnt-3a ligand Effect on the Survival of Hippocampal Neurons Exposed to the $A \beta$ peptide

\begin{tabular}{lc}
\hline Treatment & Cell Survival (\%) \\
\hline Control & $100.0 \pm 6.1$ \\
$A \beta$ & $51.4 \pm 2.9$ \\
$A \beta+$ Wnt-3A & $75.9 \pm 4.3$ \\
$A \beta+$ Wnt-3A+ heparin $0.1 \mu \mathrm{g} / \mathrm{ml}$ & $88.3 \pm 6.0 *$ \\
$A \beta+$ Wnt-3A+ heparin $1.0 \mu \mathrm{g} / \mathrm{ml}$ & $103.1 \pm 8.5 *$
\end{tabular}

Values represent means \pm s.d. of three experiments carried out in triplicate. Hippocampal neurons were pretreated with Wnt-3a ligand with or without heparin for I h previous to the addition of $5 \mathrm{mM}$ $A \beta_{I-40}$. Neurons were then incubated for $24 \mathrm{~h}$ and MTT reduction was determined. * Indicates $P<0.05$ compared with respect to $A \beta+$ Wnt-3a in a "T" test analyzed by the Sigma plot 2.0 program.

\section{The activation of the Wnt Signaling Pathway Prevents $A \beta$} induced Neurotoxicity

A considerable amount of data has led to a quest to understand the role Wnt signaling may play in AD. $\beta$-catenin levels are markedly reduced in $\mathrm{AD}$ patients carrying presenilin-1 (PS-1) inherited mutations [29]. In fact, several studies have shown that familial AD-linked PS-1 proteins form multi-protein complexes with $\beta$-catenin and GSK-3 $\beta$ [34-36]. Early studies in our laboratory suggested a relationship between $A \beta$-induced neurotoxicity and lower cytoplasmic levels of $\beta$-catenin. Inhibition of GSK-3 $\beta$ by lithium was shown to protect rat hippocampal neurons from A $\beta$-induced damage $[25,26,37]$. These evidences led us to propose that a sustained loss of Wnt signaling function could be involved in the $\mathrm{A} \beta$ dependent neurodegeneration observed in $\mathrm{AD}[24,37]$.

The enzyme GSK-3 $\beta$, a key modulator in the Wnt canonical, has its activity related with the neuropathology present in AD. GSK-3 $\beta$ is widely expressed throughout the rat CNS [38], with particularly high levels of expression in the hippocampus. In cultured hippocampal neurons, it is expressed throughout the cell bodies, including dendritic spines [39]. The presence of GSK-3 $\beta$ within dendrites and dendritic spines suggests that it may have a role in synaptic function. Recently, Collingridge and coworkers obtained evidence for a role of GSK-3 $\beta$ in NMDA receptor-dependent long-term depression (LTD) at CA3-CA1 synapses of 2-week-old rats. They found that a variety of inhibitors of GSK-3 $\beta$ were able to prevent the induction of LTD when loaded into the recorded neuron using a patch pipette. These structurally unrelated inhibitors, SB415286, lithium and kenpaullone, prevented the induction of LTD over the appropriate concentration range at which they inhibited GSK-3 $\beta$ [40]. Previous studies have shown that following the induction of LTP there is inhibition of GSK-3 $\beta$ activity [41]. In summary, GSK-3 $\beta$ is required for LTP and provides a mechanism by which LTP can inhibit LTD, therefore the regulation of GSK-3 $\beta$ activity provides a mechanism to preserve information encoded during LTP from erasure by subsequent LTD. Whether or not these functions or the deregulation of these functions are important early or late features in the development of neurodegenerative diseases remains to be determined [39].

In $\mathrm{AD}$ brain, active GSK-3 $\beta$ (also known as tau kinase I) is mainly found in neuronal cell bodies and neurites [42], where it is found co-localized with the neurofibrillary changes observed in $\mathrm{AD}$ brains. The activation of the enzyme GSK-3 $\beta$, the hyperphosphorylation of tau protein, and the loss of the microtubular network have all been observed in primary cultures of rat hippocampal and human cortical neurons exposed to the $A \beta$ peptide $[43,44]$. Interestingly, it has been observed that blocking GSK-3 $\beta$ activity prevents tau hyper-phosphorylation and promotes its binding to the microtubular network [45]. Lithium, which has long been used to treat bipolar disorders [46], has been shown to be a competitive inhibitor of GSK-3 with respect to magnesium, a property not found in other group I metal ions [47]. This may account for its ability to act as a mood-stabilizing drug [48], though other actions of lithium, such as its well-known ability to inhibit inositol-1,4 bis-phosphate 1-phosphatase and inositol-1(or 4)-mono-phosphatase, could also explain or contribute to its therapeutic effects [49]. Studies from different laboratories indicated that lithium protects rat hippocampal neurons from $A \beta$ insults suggesting that $a$ sustained loss of the Wnt signaling function may be involved in the $A \beta$ dependent neurodegeneration observed in $\mathrm{AD}[26,27]$. Furthermore, recent evidence suggests that lithium is neuro-protective against a variety of neurodegenerative conditions $[46,50]$, and it is noteworthy that lithium reduces the prevalence of AD in elderly patients with bipolar disorder [51]. Ongoing clinical trials are evaluating the efficacy of this drug to lower tau and $\beta$-amyloid levels in the cerebral spinal fluid of $\mathrm{AD}$ patients http://clinicaltrials.gov/ct2/show/ NCT00088387. Recent studies in our laboratory, using double transgenic mice $\left(\mathrm{APP}_{S W E}+\mathrm{PSEN} 1 \Delta \mathrm{E} 9\right)$ indicated that lithium injection prevents the behavioral disturbances of the animals, reducing the size of the amyloid plaque, Figure 2A, B (Toledo \& Inestrosa, unpublished results).

The exposure of rat hippocampal neurons to $A \beta$ result in three hallmarks related with Wnt signaling: (a) destabilization of endogenous levels of $\beta$-catenin, (b) an increase in GSK-3 $\beta$ activity and (c) a decrease in Wht target gene transcription. In vitro studies have shown that the activation of the canonical Wnt signaling pathway by Wnt-3a and $W n t-7 a$ conditioned media were able to overcome the neurotoxic consequences induced by A $\beta$ [52,53]. Moreover the exposure of neurons in culture to $A \beta$ induces apop- 


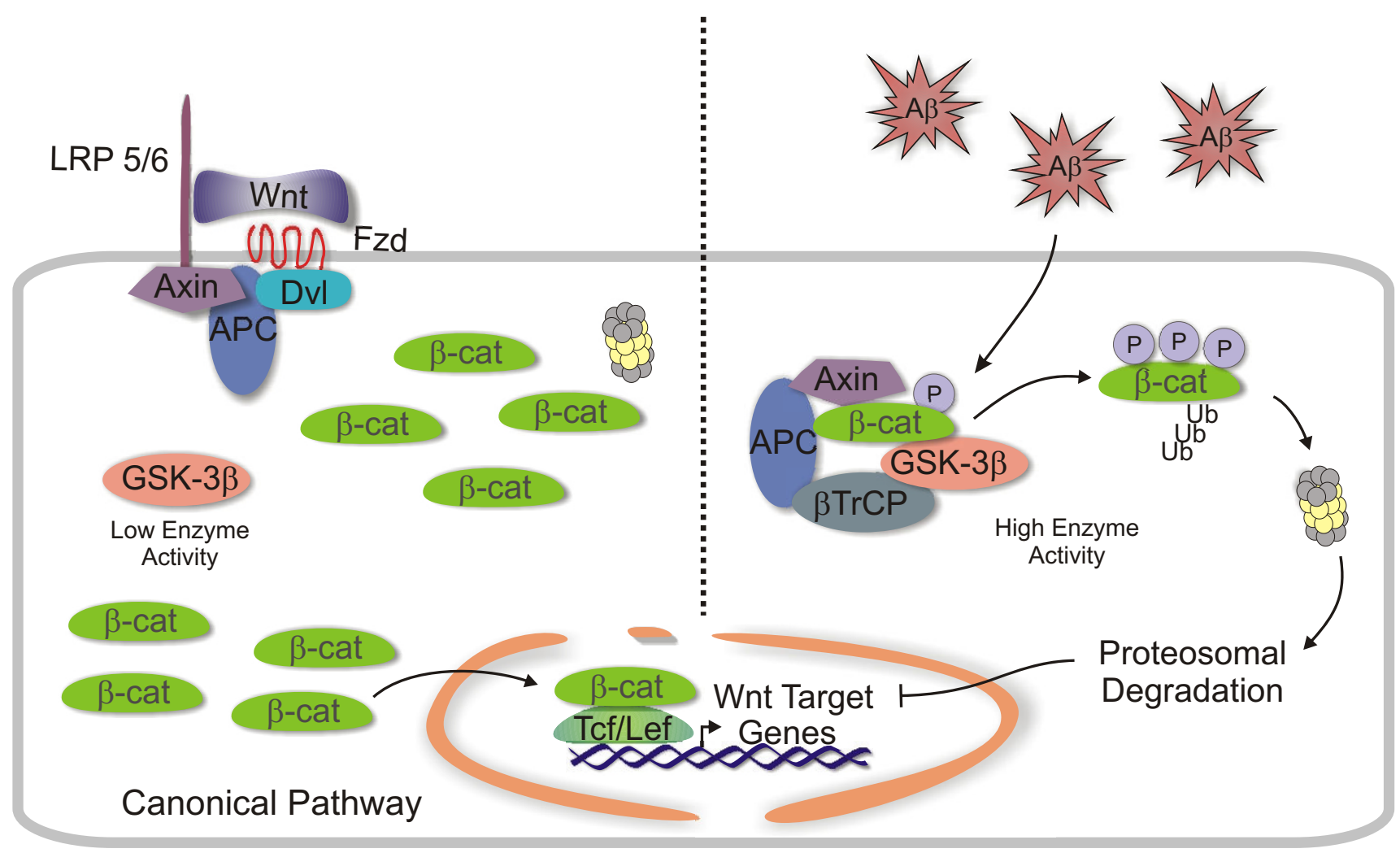

Normal Wnt Signaling

Inhibited Wnt Signaling

\section{Figure I}

The Wnt signaling pathway and its inhibition by $\mathbf{A} \beta$ aggregates. First when the Wnt ligand is available, the Fz receptor together with LRP5/6 translates its signal through Dvl, which in turn inactivates GSK-3 $\beta$ in the cytoplasmic destruction complex. This allows $\beta$-catenin to accumulate in the cytoplasm, and subsequently to move to the nucleus, where it binds to TCF/ LEF transcription factors activating Wnt target gene transcription (Left Panel). On the other hand, when the A $\beta$ aggregates become available, the signaling through the Wnt pathway might be affected: GSK-3 $\beta$ activates, $\beta$-catenin destroyed, and the Wnt mediated gene transcription is stopped (Right Panel). Several potential mechanisms of how A $\beta$ aggregates affect Wnt signaling might be possible: (a) $A \beta$ may bind to the Wnt ligand (scavenger effect), (b) $A \beta$ may directly interact with the Fz receptor, (c) Dkk-I may become available and block the transduction at the receptor level, or (d) A $\beta$ may affect calcium flux by direct activation of the $\alpha 7$-nicotinic ACh and/or NMDA receptors. As a consequence, GSK-3 $\beta$ is activated and $\beta$-catenin function attenuated.

tosis and promotes tau hyperphosphorylation through GSK-3 $\beta$ activity $[54,55]$.

The Wnt/Ca ${ }^{2+}$ pathway signals through Dvl to induce calcium influx and the activation of protein kinase $C$ (PKC) [56]. The inactivation of GSK-3 $\beta$ by PKC, leads to two main consequences: reduced phosphorylation of tau protein and reduced degradation and subsequent accumulation of cytoplasmic $\beta$-catenin $[25,53]$. PKC isoenzymes are degraded in a differential manner upon $A \beta$ exposure. The modulation of PKC affects $A \beta$ neurotoxicity, as the activation of this enzyme by phorbol-12-myristate 13-ace- tate increases cell viability of rat hippocampal neurons and neuroprotection towards A $\beta$. PKC inhibits GSK-3 $\beta$ through serine 9 phosphorylation preventing the cytoplasmic $\beta$-catenin degradation and thus, activating the transcription of Wnt target genes such as engrailed and cyclin-D1. Wnt-3a and lithium mimicked PKC activation $[25,53]$. The regulation of some components of the Wnt signaling pathway by $\mathrm{Ca}^{2+-d e p e n d e n t ~ P K C ~ i s o-f o r m s, ~}$ may be important in controlling the neurotoxic process induced by $\mathrm{A} \beta$. As a result, the activation of the Wnt signaling pathway has been proposed $[25,26,52,53,57]$ as a therapeutic target for the treatment of $\mathrm{AD}$. 
A)
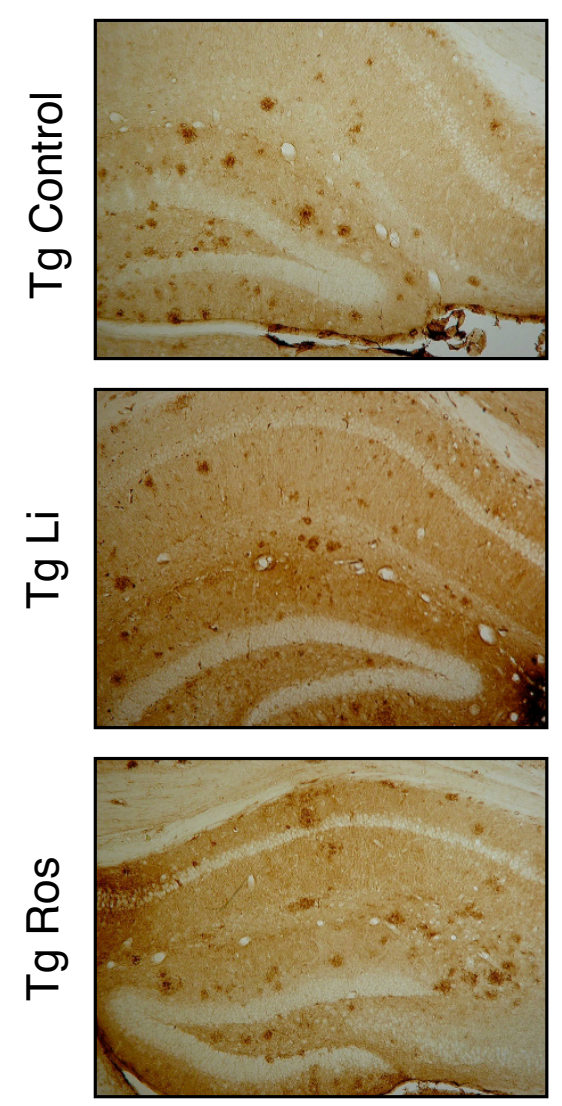

Cortex
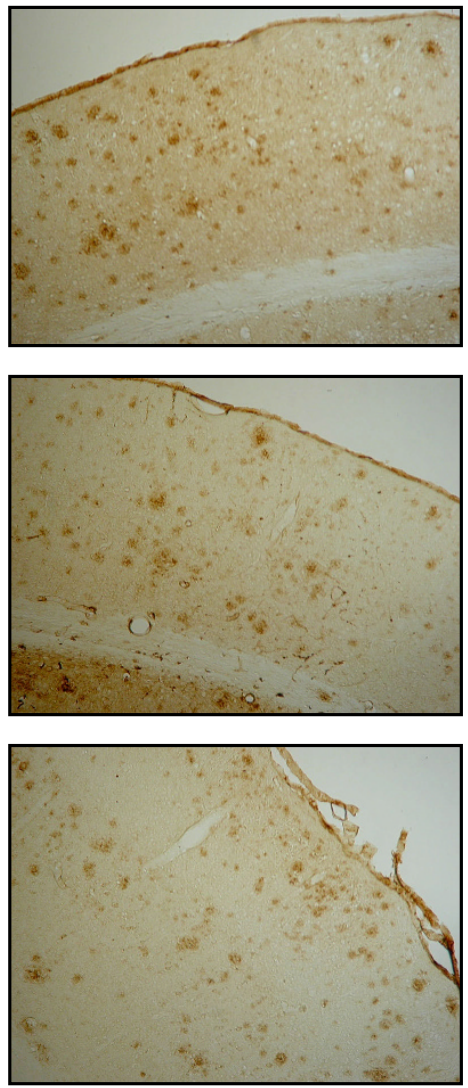

B)

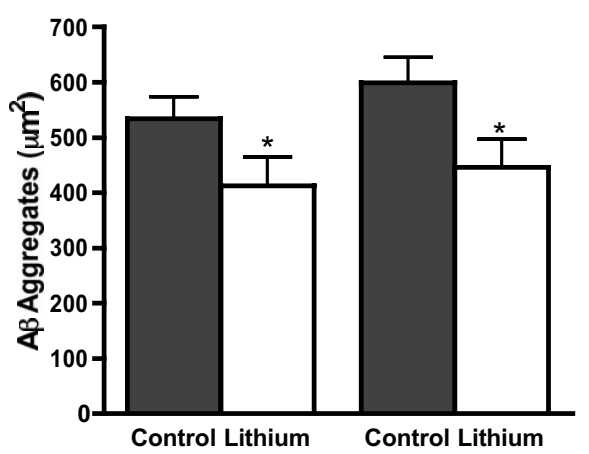

C)

Cortex Hippocampus

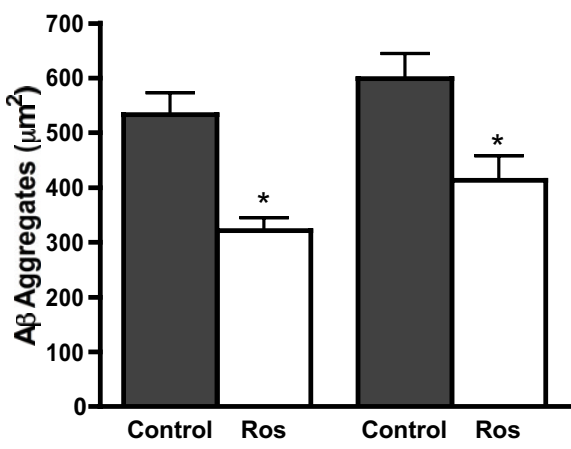

Figure 2

Treatments with Lithium and Rosiglitazone reduce the amount of total A $\beta$ in brains of APPswe+PSEN I $\triangle E 9$ mice. (A) Hippocampal and cortical slices from transgenic mice APPswe+PSENI $\triangle E 9$ (Tg) stained against A $\beta$. Photos are of Tg control and Tg treated animals with Lithium or Rosiglitazone. Figures $\mathbf{B}$ and $\mathbf{C}$ show the average $\mathbf{A} \beta$ plaque area $\left(\mu \mathrm{m}^{2}\right)$ in the hippocampus and cortex after the treatments of lithium (B) and rosiglitazone $(\mathbf{C})$ respectively, with bars representing the average plaque area for each specific treatment \pm S.E $(n=5)$. Asterisks indicate significant differences, $p<0.05$.

The loss of Wnt signaling cannot be just attributed to a loss of function. The reduction in the Wnt signaling can be due to a gain of function of inhibitors of the Wnt signaling. Studies by Caricasole et al (2004) [30] showed that the exposure of cortical neurons to $A \beta$ induced the expression of the secreted glycoprotein Dkk-1. Dkk-1 negatively modulates the canonical Wnt signaling pathway, thus activating the tau-phosphorylating enzyme GSK-3 $\beta$ [58]. Dkk-1 was induced at later times after $A \beta$ exposure, and its expression was dependent on the tumor suppressing protein p53. The antisense induced knockdown of Dkk-1 attenuates the reduction in the phosphorylated (inhibited) form of GSK-3 $\beta$, and a selective GSK-3 $\beta$ inhibitor prevents tau hyperphosphorylation in neurons challenged with $A \beta$. The Dkk-1 knockdown also attenuates neuronal apoptosis. These mechanisms may be relevant to the $\mathrm{AD}$ pathology because Dkk-1, which is hardly found in the healthy brain, is highly expressed in the AD brain where it is found around the amyloid plaques and co-localizes with neurofibrillary tangles and dystrophic neurites. These studies indicate that induction of Dkk-1 contributes to the pathological cascade triggered by $\mathrm{A} \beta$ and is critically involved in the process of tau-phosphorylation. These results strengthen the hypothesis that an impairment of the Wnt pathway contributes to the pathophysiology of $\mathrm{AD}[4,5,24,58,59]$

Another mechanism for the inhibition of the Wnt signaling is by sFRPs, which are also capable to disrupt the Wnt network signaling. Increased expression of sFRP 1, 2, 3 and 5 has been reported in Inherited Retinal Degenerations such as Retinitis Pigmentosa, which is characterized by progressive loss of photoreceptors due to apoptosis $[60,61]$. sFRPs can regulate apoptosis in vitro, in fact, 
sFRP2 a member of the family of secreted Frizzled-related proteins [62], is also known as secreted apoptosis-related protein-1 (SARP-1) [63]. They appear to interact with the $W n t / \beta$-catenin or Wnt/Frizzled signaling pathway, which includes routes to apoptotic activation. As discussed by Baranski et al (2000) [64] it is also possible that sFRPs operate agonistically to Wnt signaling in some circumstances: for example, sFRP2 (SARP-1) increases resistance of MCF7 breast adeno-carcinoma cells to apoptotic signals, whereas sFRP1 (SARP-2) sensitizes the same cell [63] via opposing effects on intracellular $\beta$-catenin levels. These results suggest that intercellular signals via the Wnt pathways are substantially disrupted in the degenerative state, and that targeting of sFRPs to key areas of the neuroretina may mediate mechanisms promoting or antagonizing cell death, similar mechanisms may also be true for neurodegenerative diseases such as AD.

Genetic epidemiological data show a link between Wnt signaling and $\mathrm{AD}$. The analysis of single-nucleotide polymorphisms show an increased risk for AD in populations with inheritance of the apo-lipoprotein E- $\varepsilon 4$ (APOE- 84 ) allele, including both sporadic and late-onset familial forms of the disease [65]. Recently, it was reported that APOE- 44 causes the inhibition of the canonical Wnt signaling pathway in PC12 cells upon stimulation with Wnt$7 a$ as determined by luciferase activities and nuclear $\beta$-catenin levels [66]. Epidemiological studies also estimates that $42-48 \%$ of AD patients do not present the APOE- $\varepsilon 4$ allele, suggesting that additional genetic or environmental factors could play essential roles in the disease [67]. Genome-wide screens have identified several regions that show significant linkage to $\mathrm{AD}$. The reported linkage peaks of chromosome 12 show significant association with $\mathrm{AD}$, particularly one region located in the vicinity of the LRP 6 [32]. Since LRP5/ 6 encodes a co-receptor for the Wnt pathway, its association with AD was studied. Results unveil an association between a highly conserved coding sequence LRP 6 polymorphism (Ile1062Val) and the risk to develop late-onset $\mathrm{AD}$ in $\mathrm{APOE}-\varepsilon 4$ allele carriers. Interestingly, the Val 1062 variant of LRP 6 causes a reduced activation of a $\beta$-catenin-responsive reporter gene in HEK293T/STF recombinant cells [32], suggesting that a reduced efficiency of the canonical Wnt signaling pathway may predispose people to AD.

Accumulation of cytoplasmic inclusion bodies in many neurodegenerative diseases, including $\mathrm{AD}$, might result from dysfunction of the ubiquitin-proteasome system $[68,69]$. This system degrades many cellular proteins, including $\beta$-catenin. Wnt signaling activation causes the dissociation of the multiprotein complex that contains, among others, GSK-3 $\beta$ and $\beta$-catenin. This prevents GSK$3 \beta$ from phosphorylating $\beta$-catenin [70]. Un-phosphorylated $\beta$-catenin becomes resistant to proteosomal degra- dation [71] and moves to the nucleus, where it regulates gene expression after interacting with members of the TCF/LEF family of transcription factors. Genes that are affected by the canonical Wnt pathway are involved in the regulation of neuronal survival and homeostasis (such Bcl-2, $\alpha 7$-nicotinic AChR, insulin degrading enzyme, CaMKIV and neuroligin) [72-76]. Phosphorylation of $\beta$ catenin labels it for ubiquitination and rapid proteasomal degradation. Studies by Ghanevati and Miller (2005) [31] indicated that phospho- $\beta$-catenin accumulated as detergent-insoluble, punctuate cytoplasmic inclusions in hippocampal pyramidal neurons more abundantly in $\mathrm{AD}$ brain than in aged controls. Phospho- $\beta$-catenin is partially sequestered within granulo-vacuolar degeneration bodies but not lysosomes, indicating sequestration within autophagosomes. Exposure of neuronal cultures to proteasome inhibitors induced formation of detergent-insoluble, phospho- $\beta$-catenin-positive cytoplasmic inclusions that coalesced into aggresomes and colocalized with $\gamma$ tubulin and vimentin. These aggregates were associated with apoptotic cell death and with activation of caspase-3, c-Jun-N-terminal kinases, and c-Jun [31]. These findings suggest that the accumulation of phospho- $\beta$-catenin in $\mathrm{AD}$ result from impaired proteasomal function. Recently, it was found that the up-regulation of $\beta$-catenin during tau-hyperphosphorylation prevents neuronal cells from going into apoptosis. Furthermore, increasing levels of hyperphosphorylated tau was correlated with diminished levels of phospho- $\beta$-catenin and increased levels of nuclear $\beta$-catenin. Moreover, the knockdown of $\beta$-catenin increases the number of apoptotic cells and antagonizes the anti-apoptotic effects of tau [77]. These results support the role of $\beta$-catenin and therefore the $\mathrm{Wnt} / \beta$-catenin signaling in neuronal survival following $A \beta$ insult in $A D$.

In mammals, Fz genes have been implicated in a variety of developmental processes, including axonal outgrowth and guidance in the central nervous system $[78,79]$, the survival of cerebellar neurons [80], hippocampal and visuospatial learning [81], and the control of the neural tube closure [82]. Rat Fz1 and Fz2 have been studied in greatest detail and provide the best discrimination of the Wnt pathways, referred to as $W n t / \beta$-catenin pathway $[83,84]$, versus the $W n t-\mathrm{Ca}^{2+}$ pathway $[23,85]$. An exhaustive study of the possible associations between the known 19 Wnt ligands and the $10 \mathrm{Fz}$ has not been carried out, although some combinations seem to convey a meaningful intracellular signal $[86,87]$, including human Fz1 and Wnt-3a [88], and Fz5 and Wnt-7a [89]. Although Wnt signaling pathway and $\mathrm{Fz}$ receptors have been shown to participate in the development and maintenance of the nervous system, little is known about the expression of $\mathrm{Fz}$ in the mammalian brain. Through the analysis of in-situ hybridization of adult mice brains, it was found that numerous $\mathrm{Fz}$ receptors and Wnt ligands are expressed across the 
brain [90]. Knowledge of the pattern of expression of $\mathrm{Fz}$ receptors and Wnt ligands, may contribute to the understanding of the in vivo Wnt signaling in the adult brain. More recently, a high-throughput methodology that allows the analysis of expression of 20000 genes, revealed that the adult brain of mice expresses different components of the Wnt signaling pathway [91].

The activation of the canonical Wnt signaling pathway protects hippocampal neurons against the toxicity of Alzheimer's $A \beta$, however, the role played by the Wnt receptors $\mathrm{Fz}$ has not been studied. Recently we found that Fz1 mediates the activation of the canonical $W n t / \beta$-catenin pathway by $W n t-3 a$ in PC12 cells. In addition, the protective effect of Wnt-3a against the toxicity of $A \beta$ oligomers was modulated by Fz1 expression levels. Overexpression of $\mathrm{Fz} 1$ significantly increased cell survival induced by Wnt-3a and diminished caspase- 3 activation and $\beta$-catenin degradation, these Wnt-3a effects are potentiated by over-expression of Fz1, but not Fz2, and are significantly reduced when Fz1 is knocked down by antisense oligonucleotides in PC12 cells [92]. Overexpression of wild-type $\beta$-catenin, but not a transcriptionally inactive mutated version, prevented the toxicity of $A \beta$ suggesting that the transcription of Wnt target genes may be involved in these events. This was confirmed by cotransfecting both Fz1 and the inactive form of $\beta$-catenin, which did not elicit protection levels similar to those shown with endogenous $\beta$-catenin. Fz1 is expressed in the adult rat hippocampus and cortex, and in cultured hippocampal neurons where Wnt-3a also protects against $\mathrm{A} \beta$ toxicity, an effect that was decreased by knocking-down $\mathrm{Fz} 1$ expression [92]. The neuro-protective effect of Wnt-3a modulated by Fz1 expression suggests that the activation of the canonical Wnt signaling pathway prevents the neurotoxicity induced by the $A \beta$ peptide and again suggest a therapeutic potential for this signaling pathway in the treatment of $\mathrm{AD}$.

The signal transduction mechanisms involved in $A \beta$ induced neuronal dysfunction remain to be fully understood; the identity of the protein receptor(s) involved in neuronal $A \beta$ binding has not been identified. Studies by Ferreira and coworkers in Brazil [93], have identified a number of peptides that bind $A \beta$ and are homologous to neuronal receptors putatively involved in $\mathrm{A} \beta$ interactions, using phage display of peptide libraries $[33,94]$. Through this methodology they have found an heptapeptide called IQ, which is common to nAChRs with the ability to bind $\mathrm{A} \beta$ with a nanomolar affinity [94]. This binding is enough to block the inhibition of $n A C h R s$ by $A \beta$ when it was studied in PC12 cells. These results demonstrate that a region found in nAChRs acts as a receptor to $A \beta$ and allow us to hypothesize the role of $n A C h R s$ as receptors of $A B$ in the CNS. More recently, Ferreira and coworkers reported a cysteine-linked cyclic heptapeptide (denominated cSP) that is highly homologous to the extracellular cysteinerich domain (CRD) of several members of the Fz family of $W n t$ receptors. Based on this homology, they investigated the interaction between $A \beta$ and $F z$, and found that $A \beta$ binds to the Fz CRD at or in close proximity to the Wnt binding site and inhibits $\beta$-catenin accumulation, nuclear translocation and Wnt-targeted gene transcription [33]. Interestingly, the cSP peptide completely blocks $\mathrm{A} \beta$ binding to $\mathrm{Fz}$ and prevents inhibition of the Wnt signaling cascade. These results indicate that the $\mathrm{A} \beta$ binding site in $\mathrm{Fz}$ is homologous to cSP and that this is a relevant target for $\mathrm{A} \beta$ neurotoxicity. Furthermore, they suggest that blocking the interaction of $\mathrm{A} \beta$ with $\mathrm{Fz}$ might lead to novel therapeutic approaches to prevent neuronal dysfunction in AD.

\section{Cross-talk of different signaling pathways with the Wnt Pathway leads to neuroprotection against $\boldsymbol{A} \beta$ Neurotoxicity}

The emerging role of Wnt signaling as a therapeutic target for treatment of AD led us to evaluate potential pathways that interact with the Wnt signaling:

(a) Cholinergic dysfunction has been observed in $\mathrm{AD}$ patients, indicating its relationship with $A \beta$ neurotoxicity. Degenerated pre-synaptic cholinergic neurons that ascend from the basal forebrain to cortical and hippocampal areas have been observed [95]. In relation to $\mathrm{AD}$, it is well known that M1 agonists increase the non-amyloidogenic processing of the amyloid precursor protein (APP), reducing $A \beta$ production [96] and tau phosphorylation [97]. In addition, M1 muscarinic receptor activation by the specific agonist AF267B induces the phosphorylation/inactivation of GSK-3 $\beta$ in cortical neuronal cultures from transgenic mice that overexpress GSK-3 $\beta$. A $\beta$ treatment, as well as transgenic mice that over-express GSK-3 $\beta$, shows decreased levels of Ser-9 phosphorylation, thus GSK-3 $\beta$ is activated. On the contrary, M1 agonist treatments decrease GSK-3 $\beta$ activity. In this manner, Ser-9 phosphorylation/inactivation of GSK-3 $\beta$ by M1 mAChR stimulation is probably mediated by a mechanism that involves protein kinase C (PKC), since a PKC inhibitor blocked M1 muscarinic receptor activation-induced Ser-9 phosphorylation. Interestingly, it has been shown that PKC protects from apoptosis induced by $A \beta[23,98]$. Hippocampal neurons exposed to $A \beta$ toxicity induced the activation of GSK$3 \beta$, which was prevented by the activation of M1 muscarinic receptor. The protection observed in vitro was later found in vivo; chronic treatment with the specific M1 agonist $A F 267 \mathrm{~B}$, improved the spatial memory and reduced the $A \beta$ load in the hippocampus of a triple transgenic mouse [99]. Thus, the M1 muscarinic activation and the Wnt signaling pathway interact, leading to potential neuroprotection against $A \beta$ toxicity. 
(b) The use of non-steroidal anti-inflammatory drugs (NSAIDs) has been observed to reduce the risk for $\mathrm{AD}$ [100]. The NSAIDs have been proposed to act by inhibiting the secretases that cleave the APP in the amyloidogenic pathway to render $A \beta$. Moreover, NSAIDs dramatically reduce the secretion of $A \beta_{1-42}$ in cells in vitro [101-104]. A bi-functional compound that includes Ibuprofen (an anti-inflammatory drug) and prostigmine (a cholinesterase inhibitor), IBU-PO protects hippocampal neurons from $A \beta$ neurotoxicity, increases the viability of $\mathrm{A} \beta$-challenged hippocampal neurons, and enhances neurite growth [105]. The protection observed is the result of the Wnt signaling activation, since the increase in the activity of GSK- $3 \beta$ induced by $A \beta$ is down-regulated by cotreatment with IBU-PO. In addition, this down-regulation occurs through induction of Ser-9 phosphorylation. Transgenic mice that over-express GSK-3 $\beta$ show low levels of Ser-9 phosphorylation and the IBU-PO treatment induces an increase in this phosphorylation [105]. Compounds such as IBU-PO, which mimic the activation of the Wnt signaling pathway, could eventually rescue neurons from cytotoxicity through GSK- $3 \beta$ inhibition, which may be of potential benefit for the treatment of $\mathrm{AD}$ patients.

(c) Treatment with some antioxidants has been suggested as an avenue for the treatment of $\mathrm{AD}$ [106]. We have studied whether or not some antioxidants are able to affect the canonical Wnt signaling pathway. Treatments with Trolox (an hydro-soluble analogue of vitamin E) and $17 \beta$-estradiol, but not vitamin $C$, increases the cytoplasmic levels of $\beta$-catenin and inhibits the increase in GSK-3 $\beta$ activity observed when neurons are exposed to $A \beta$ [52]. In this context, we ask whether or not the activation of the Wnt signaling by anti-oxidant treatment increases the mRNA levels of some of the components of the Wnt pathway. Results indicated that both Wnt-7a and Wnt-5a ligands were induced by the anti-oxidant treatment [52]. A similar effect was observed for engrailed-1 mRNA. In this context, it is interesting to mention that at least $4 \mathrm{Wnt}$ ligands (Wnts 4, 11, 5a and 7a) present in embryonic hippocampal neurons are also expressed in the adult rat brain [107], indicating that at least some of the Wnt ligands are present throughout the entire lifespan of mammals.

(d) The relative importance of hydrogen peroxide and free radicals in the neurodegenerative processes triggered by $A \beta$ had been previously addressed [106]. For example, Schubert and coworkers [108], demonstrated that the addition of catalase (an enzyme that inactivates hydrogen peroxide) to neuronal cultures exposed to $A \beta$, results in the prevention of neurodegenerative changes. More recently, we found that proliferation of peroxisomes, intracellular organelles that destroy the excess of cellular hydrogen peroxide, also prevent the neurotoxic effects generated by A $\beta$ in rat hippocampal cells [109]. The drugs used to trigger the peroxisomal proliferation normally activate a member of a family of nuclear receptors known as peroxisome proliferator activated receptors (PPAR), particularly the PPAR $\alpha$. Such drugs increase $\beta$-catenin content in hippocampal neurons, suggesting an interaction with the Wnt signaling pathway [109].

Another PPAR, known as the PPAR $\gamma$, plays an important role in the regulation of lipid metabolism [110]. In addition, PPAR $\gamma$ is the target of the insulin-sensitizing thiazolidinediones (TZDs) drugs, used to treat type II diabetes. Recent studies suggest that treatment of insulin resistance with a PPAR $\gamma$ agonist retards the development of $\mathrm{AD}$ [111], and TZDs have been proposed as potential therapeutic agents for both diabetes and $\mathrm{AD}$ [112]. Most of the neuroprotective effects of TZDs are ascribed to either improved insulin sensitivity or to their anti-inflammatory action through PPAR $\gamma$ activation in reactive astrocytes and microglia $[113,114]$. Studies in our laboratory, demonstrated that the activation of PPAR $\gamma$ by three different TZDs was able to prevent the neurodegeneration induced by the A $\beta$. The activation with the PPAR $\gamma$ agonists modulate Wnt signaling components, including the inhibition of GSK-3 $\beta$ activity, the increase in both the cytoplasmic and nuclear levels of $\beta$-catenin, as well as the transcription of Wnt target genes en-1 and cyclin-D1 [115]. Previous studies in our laboratory indicated that Bcl-2 may be a Wnt target gene $[72,116]$. Recent studies with neurons containing high and low PPAR $\gamma$ levels, suggest that $\mathrm{Bcl}-2$ plays a key role in the neuroprotection to both hydrogen peroxide and $A \beta$ [72]. In fact, NGF-differentiated PC12 neuronal cells that over-express PPAR $\gamma$ are resistant to A $\beta$ induced apoptosis and to ROS increase after exposure to hydrogen peroxide. Conversely, cells expressing a dominant negative mutant of PPAR $\gamma$ show increased A $\beta$ induced apoptosis and alterations by oxidative stress. Neurons over-expressing PPAR $\gamma$ show a 4.5 -fold increase in $\mathrm{Bcl}-2$ content, whereas in dominant negative PPAR $\gamma$ expressing cells, $\mathrm{Bcl}-2$ is barely detected. Bcl-2 knockdown by siRNA in neurons over-expressing PPAR $\gamma$ results in increased sensitivity to $A \beta$ and oxidative stress. Finally, PPAR $\gamma$ pro-survival action is independent of the signal regulated MAPK or the Akt pathways [72]. These results suggest that PPAR $\gamma$ supports neuronal survival by a mechanism that involves an increased expression of Bcl-2. An alternative mechanism that could protect neurons from the $A \beta$ toxicity has been proposed. In fact, TZD, an agonist of PPAR $\gamma$, induced an increase in the clearance mechanism of the $A \beta$ peptide [117]. Interestingly, the activation of PPAR $\gamma$ by rosiglitazone improves learning and memory in a mouse model of $A D$, together with a reduction in $A \beta$ in the brains of Tg mice [118]. Recent studies in our laboratory, using the $\mathrm{APP}_{\mathrm{SWE}}+\mathrm{PSEN} 1 \triangle \mathrm{E} 9$ double transgenic mice, indicated that rosiglitazone administration prevents 
A)
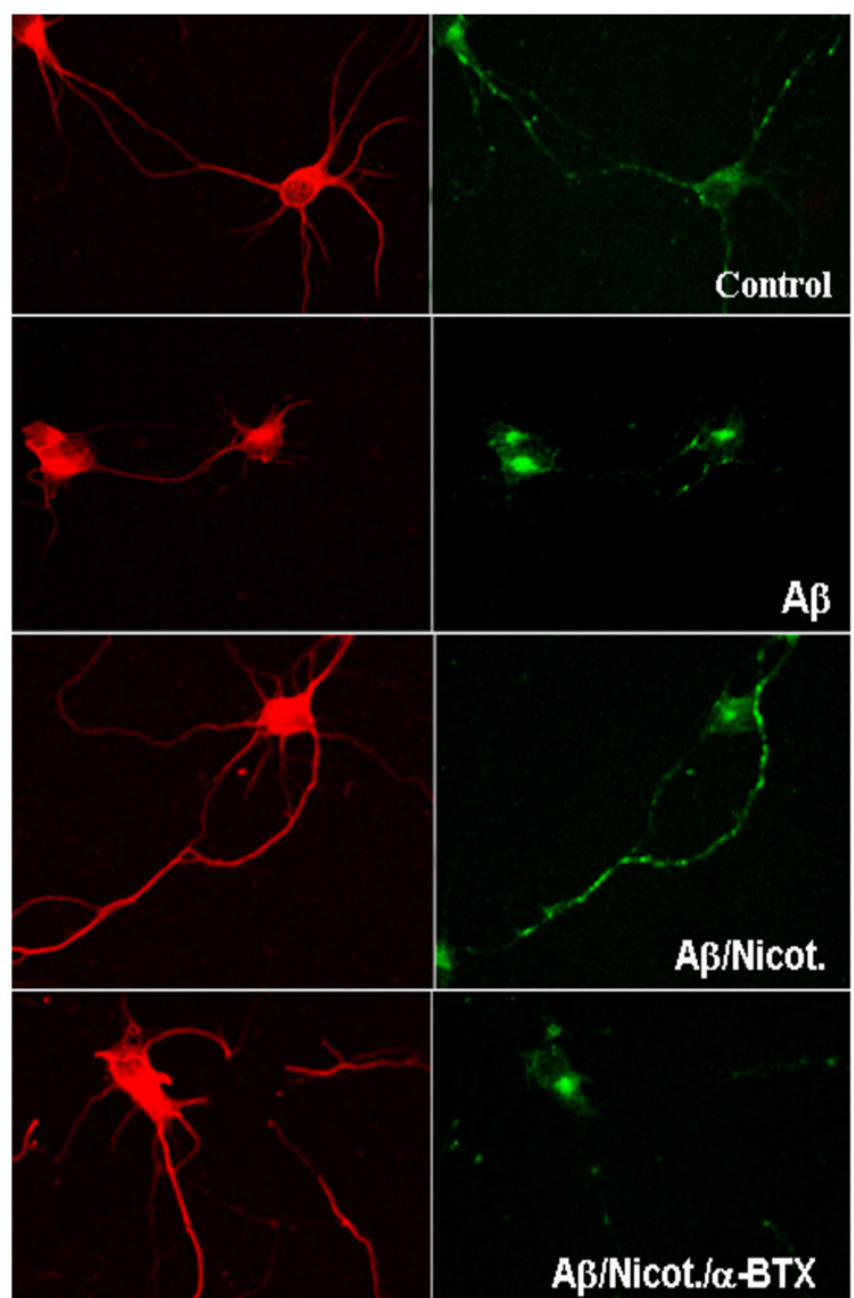

NF
B)

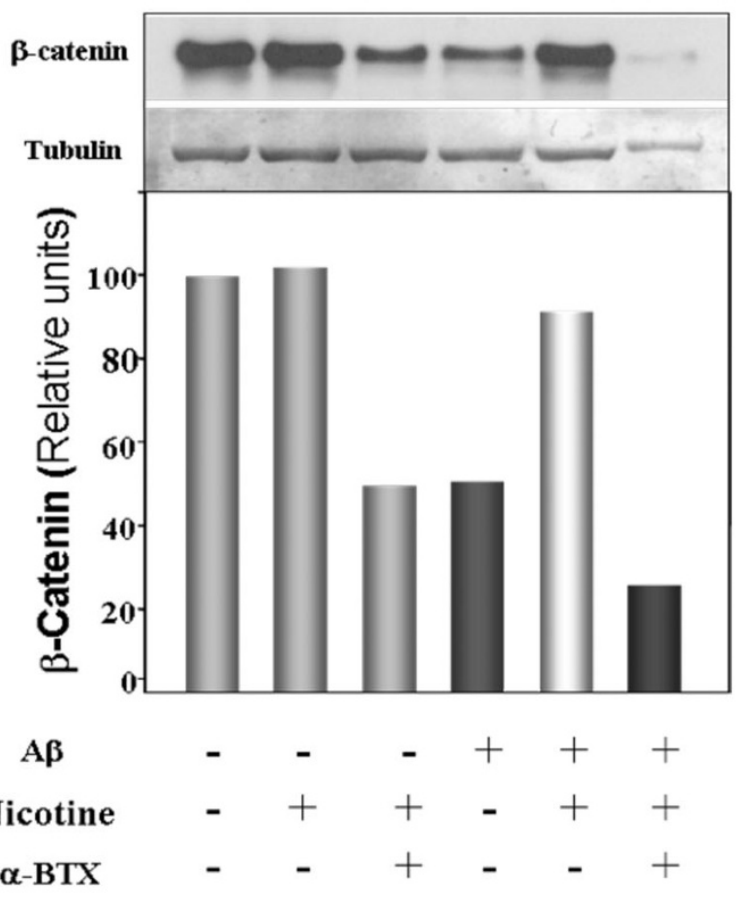

\section{Figure 3}

Activation of $\alpha$ 7nAChR with nicotine protects hippocampal neurons from $\mathbf{A} \beta$ fibers. (A) Hippocampal neurons (I0 DIV) were expose to $A \beta_{I-40}$ fibers $5 \mathrm{mM}$ for $6 \mathrm{~h}$ in the absence or presence of nicotine $10 \mu \mathrm{M}$. The immunostainings of the protein neurofilament (NF) shows the loss of dendrites, and the presynaptic protein SV-2, show a significant reduction upon exposure to $A \beta$. Nicotine is able to overturn the damage cause by $A \beta$. This reversion is specific to the nicotinic receptor since this protective effect was blocked by $\alpha$-bungarotoxin (100 nM). (B) These effects are observed by western-blot of the total levels of total $\beta$-catenin, in which the reduction of $\beta$-catenin is prevented by nicotine and blocked with $\alpha$-BTX.

the behavioral and the inflammatory-glial disturbances observed in transgenic animals, thus reducing amyloid plaque size, Figure 2A,C (Toledo \& Inestrosa, unpublished results).

(e) Recently, we reported that Wnt-7a induces dissociation of the APC protein from the $\alpha$-catenin cytoplasmic complex and the interaction of APC with the $\alpha 7-n A C h R$ in hippocampal neurons. In the CNS, $\alpha 7-n A C h R s$ are involved in several aspects of brain function, affecting neuronal development [119], learning, and memory
[120]. Because of their high permeability to calcium ions, $\alpha 7-n A C h R s$ influence synaptic efficacy and induction of LTP [121]. In Parkinson's and $\mathrm{AD}$, a decrease in the amount of $\alpha 7$-nAChRs has been found $[122,123]$. Wnt-7a is able to induce the re-localization of APC to membranes, clustering of APC in neurites, and co-clustering of APC with the presynaptic protein markers, including P-synapsin, SV2, and synaptotagmin. Moreover, Wnt-7a also increases the number and size of co-clusters of $\alpha 7$ nAChRs and APC in pre-synaptic nerve terminals [73]. These short-term changes in $\alpha 7$-nAChRs take place within 
a few minutes after ligand exposure and involve translocation to the plasma membrane without affecting total levels of the receptor. Long-term exposure to Wnt-7a increases both nAChR $\alpha 7$ subunit levels in an APC independent manner and clusters of $\alpha 7$-nAChRs in neurites via an APC dependent process [73]. These results suggest that $\alpha 7$-nAChR could be a target of the Wnt pathway by regulating the pre-synaptic localization of APC and $\alpha 7$ nAChRs, with APC serving as an intermediary in the $\alpha 7$ nAChR re-localization process. Activation of $\alpha 7-n A C h R$ with nicotine protects culture of hippocampal neurons from $A \beta$ aggregates and this protective effect of nicotine was blocked by $\alpha$-bungarotoxin. These effects are observed at the immunofluorescence level, as well as at the level of $\beta$-catenin by western blot (Figure 3 ).

Modulation by Wnt signaling may be essential for $\alpha 7$ $\mathrm{nAChR}$ expression and function in synapses. Perhaps therapies aimed to activate Wnt signaling could be effective in treatment of $\mathrm{AD}$, especially if they prevent loss of $\alpha 7$ nAChRs from synaptic regions, as well as of other important synaptic proteins. These compounds and new ones yet to be discovered, which inhibit the GSK-3 $\beta$ activity and/or enhance Wnt signaling, could lead to the reduction of neuropathological factors involved in $\mathrm{AD}$. The crosstalk of the Wnt signaling pathway with other cellular pathways is opening new possibilities for therapy.

\section{Conclusion}

Several lines of evidence indicate that deregulated Wnt signaling may play a role in the pathogenesis of $\mathrm{AD}$. The potential use of GSK-3 $\beta$ as a clinical target in AD has been discussed, including the activation of M1 muscarinic receptor and $\mathrm{PKC}$, the use of anti-inflammatory-ChE bifunctional compounds, PPAR agonists, and some antioxidants, all of which may play a role by regulating the $W n t / \beta$-catenin signaling. So far the mechanisms by which extracellular $A \beta$ causes its different intra-neuronal effects have not been clarified. Wnt-7a signaling stimulates clustering of pre-synaptic proteins and modulates the synaptic vesicle cycle by inducing recycling and exocytosis of synaptic vesicles. $A \beta$ oligomers bind to the central synapse at the postsynaptic region, and we have found that Wnt-5a plays an attenuating role in $A \beta$ neurotoxicity. In addition, this ligand modulates the insertion of glutamate receptors in the postsynaptic region of synapses. All of these data opens a novel therapeutic window in AD treatment.

\section{Competing interests}

The authors declare that they have no competing interests.

\section{Authors' contributions}

NCI participated in the design of the review and writing of the manuscript. EMT performed some experiments presented, and contribute to the writing and revision of the manuscript. Both authors read and approved the final manuscript.

\section{Acknowledgements}

This work was supported by grants from CONICYT through a Base Center for Excellence in Science and Technology, FONDAP-Biomedicine $\mathrm{N}^{\circ}$

I398000 I, the Millennium Institute for Fundamental and Applied and Biology (MIFAB) to $\mathrm{NCl}$, a predoctoral fellowship from DIPUC to E.M.T.

\section{References}

I. Selkoe DJ: Alzheimer's disease is a synaptic failure. Science 2002, 298:789-79I.

2. Logan CY, Nusse $R$ : The Wnt signaling pathway in development and disease. Annu Rev Cell Dev Biol 2004, 20:78I-8I0.

3. Nusse R: Wnt signaling and stem cell control. Cell Res 2008, I8:523-527.

4. Inestrosa N, De Ferrari GV, Garrido JL, Alvarez A, Olivares GH, Barria $\mathrm{MI}$, Bronfman $\mathrm{M}$, Chacon MA: Wnt signaling involvement in $\beta$ amyloid-dependent neurodegeneration. Neurochem Int 2002, 41:34I-344.

5. Caricasole A, Copani A, Caruso A, Caraci F, lacovelli L, Sortino MA, Terstappen GC, Nicoletti F: The Wnt pathway, cell-cycle activation and $\beta$-amyloid: novel therapeutic strategies in Alzheimer's disease? Trends Pharmacol Sci 2003, 24:233-238.

6. Moon RT, Kohn AD, De Ferrari GV, Kaykas A: WNT and $\beta$-catenin signalling: diseases and therapies. Nat Rev Genet 2004, 5:69l-701.

7. Gordon MD, Nusse R: Wnt signaling: multiple pathways, multiple receptors, and multiple transcription factors. J Biol Chem 2006, 28 I:22429-22433.

8. Mikels AJ, Nusse R: Wnts as ligands: processing, secretion and reception. Oncogene 2006, 25:746I-7468.

9. Dale TC: Signal transduction by the Wnt family of ligands. Biochem J 1998, 329(Pt 2):209-223.

10. Niehrs C: Function and biological roles of the Dickkopf family of Wnt modulators. Oncogene 2006, 25:7469-748I.

II. Diep DB, Hoen N, Backman M, Machon O, Krauss S: Characterisation of the Wnt antagonists and their response to conditionally activated Wnt signalling in the developing mouse forebrain. Brain Res Dev Brain Res 2004, 1 53:26I-270.

12. Mao B, Wu W, Li Y, Hoppe D, Stannek P, Glinka A, Niehrs C: LDLreceptor-related protein 6 is a receptor for Dickkopf proteins. Nature 200I, 4I I:32I-325.

13. Perrimon N, Bernfield M: Specificities of heparan sulphate proteoglycans in developmental processes. Nature 2000, 404:725-728.

14. Binari RC, Staveley BE, Johnson WA, Godavarti R, Sasisekharan R, Manoukian AS: Genetic evidence that heparin-like glycosaminoglycans are involved in wingless signaling. Development 1997, 1 24:2623-2632.

15. Lin X, Perrimon N: Dally cooperates with Drosophila Frizzled 2 to transduce Wingless signalling. Nature 1999, 400:28I-284.

16. Baeg GH, Lin X, Khare N, Baumgartner S, Perrimon N: Heparan sulfate proteoglycans are critical for the organization of the extracellular distribution of Wingless. Development 200I, I 28:87-94.

17. Colombres M, Henriquez JP, Reig GF, Scheu J, Calderon R, Alvarez A, Brandan E, Inestrosa NC: Heparin activates Wnt signaling for neuronal morphogenesis. J Cell Physiol 2008, 216:805-815.

18. Moon RT, DeMarais A, Olson DJ: Responses to Wnt signals in vertebrate embryos may involve changes in cell adhesion and cell movement. J Cell Sci Suppl 1993, 17:183-188.

19. Du SJ, Purcell SM, Christian JL, McGrew LL, Moon RT: Identification of distinct classes and functional domains of Wnts through expression of wild-type and chimeric proteins in Xenopus embryos. Mol Cell Biol 1995, I 5:2625-2634.

20. Mikels AJ, Nusse R: Purified Wnt5a protein activates or inhibits $\beta$-catenin-TCF signaling depending on receptor context. PLoS Biol 2006, 4:el I5.

21. Kohn AD, Moon RT: Wnt and calcium signaling: $\beta$-catenin-independent pathways. Cell Calcium 2005, 38:439-446. 
22. Miller JR, Hocking AM, Brown JD, Moon RT: Mechanism and function of signal transduction by the Wnt/ $\beta$-catenin and Wnt/ Ca2+ pathways. Oncogene 1999, 18:7860-7872.

23. Kuhl M, Sheldahl LC, Park M, Miller JR, Moon RT: The Wnt/Ca2+ pathway: a new vertebrate $W$ nt signaling pathway takes shape. Trends Genet 2000, 16:279-283.

24. De Ferrari GV, Inestrosa NC: Wnt signaling function in Alzheimer's disease. Brain Res Brain Res Rev 2000, 33:1-12.

25. Garrido JL, Godoy JA, Alvarez A, Bronfman M, Inestrosa NC: Protein kinase $C$ inhibits amyloid $\beta$ peptide neurotoxicity by acting on members of the Wnt pathway. FASEB J 2002, 16:1982-1984.

26. De Ferrari GV, Chacon MA, Barria MI, Garrido JL, Godoy JA, Olivares G, Reyes AE, Alvarez A, Bronfman M, Inestrosa NC: Activation of Wnt signaling rescues neurodegeneration and behavioral impairments induced by $\beta$-amyloid fibrils. Mol Psychiatry 2003, 8:195-208

27. Alvarez G, Munoz-Montano JR, Satrustegui J, Avila J, Bogonez E, DiazNido J: Regulation of tau phosphorylation and protection against $\beta$-amyloid-induced neurodegeneration by lithium. Possible implications for Alzheimer's disease. Bipolar Disord 2002, 4:153-165.

28. Takashima A, Murayama M, Murayama O, Kohno T, Honda T, Yasutake K, Nihonmatsu N, Mercken M, Yamaguchi $H$, Sugihara S, Wolozin B: Presenilin I associates with glycogen synthase kinase-3 $\beta$ and its substrate tau. Proc Natl Acad Sci USA 1998, 95:9637-964I.

29. Zhang Z, Hartmann H, Do VM, Abramowski D, Sturchler-Pierrat C, Staufenbiel M, Sommer B, Wetering M van de, Clevers H, Saftig P, et al.: Destabilization of $\beta$-catenin by mutations in presenilin-I potentiates neuronal apoptosis. Nature 1998, 395:698-702.

30. Caricasole A, Copani A, Caraci F, Aronica E, Rozemuller AJ, Caruso A, Storto M, Gaviraghi G, Terstappen GC, Nicoletti F: Induction of Dickkopf-I, a negative modulator of the Wnt pathway, is associated with neuronal degeneration in Alzheimer's brain. J Neurosci 2004, 24:602 I-6027.

31. Ghanevati M, Miller CA: Phospho- $\beta$-Catenin Accumulation in Alzheimer's Disease and in Aggresomes Attributable to Proteasome Dysfunction. J Mol Neurosci 2005, 25:79-94.

32. De Ferrari GV, Papassotiropoulos A, Biechele T, Wavrant De-Vrieze F, Avila ME, Major MB, Myers A, Saez K, Henriquez JP, Zhao A, et al.: Common genetic variation within the low-density lipoprotein receptor-related protein 6 and late-onset Alzheimer's disease. Proc Natl Acad Sci USA 2007, 104:9434-9439.

33. Magdesian MH, Carvalho MM, Mendes FA, Saraiva LM, Juliano MA Juliano L, Garcia-Abreu J, Ferreira ST: Amyloid- $\beta$ binds to the extracellular cysteine-rich domain of Frizzled and inhibits Wnt/B-catenin signaling. I Biol Chem 2008, 283:9359-9368.

34. Yu G, Chen F, Levesque G, Nishimura M, Zhang DM, Levesque L, Rogaeva $E, X u D$, Liang $Y$, Duthie $M$, et al.: The presenilin I protein is a component of a high molecular weight intracellular complex that contains $\beta$-catenin. J Biol Chem 1998, 273: I 6470- 16475.

35. Nishimura M, Yu G, Levesque G, Zhang DM, Ruel L, Chen F, Milman $P$, Holmes E, Liang Y, Kawarai T, et al.: Presenilin mutations associated with Alzheimer disease cause defective intracellular trafficking of $\beta$-catenin, a component of the presenilin protein complex. Nat Med 1999, 5:164-169.

36. Kang DE, Soriano S, Frosch MP, Collins T, Naruse S, Sisodia SS, Leibowitz G, Levine F, Koo EH: Presenilin I facilitates the constitutive turnover of $\beta$-catenin: differential activity of Alzheimer's disease-linked PSI mutants in the $\beta$-catenin-signaling pathway. J Neurosci 1999, 19:4229-4237.

37. Inestrosa NC, Alvarez A, Godoy J, Reyes A, De Ferrari GV: Acetylcholinesterase-amyloid- $\beta$-peptide interaction and Wnt signaling involvement in $\mathbf{A} \beta$ neurotoxicity. Acta Neurol Scand Suppl 2000, 176:53-59.

38. Leroy K, Brion JP: Developmental expression and localization of glycogen synthase kinase-3 $\beta$ in rat brain. J Chem Neuroanat 1999, 16:279-293.

39. Peineau S, Bradley C, Taghibiglou C, Doherty A, Bortolotto ZA Wang YT, Collingridge GL: The role of GSK-3 in synaptic plasticity. Br J Pharmacol 2008, I53(Suppl I):S428-437.

40. Peineau S, Taghibiglou C, Bradley C, Wong TP, Liu L, Lu J, Lo E, Wu $D$, Saule E, Bouschet T, et al.: LTP inhibits LTD in the hippocampus via regulation of GSK3 $\beta$. Neuron 2007, 53:703-717.
4I. Hooper C, Markevich V, Plattner F, Killick R, Schofield E, Engel T, Hernandez F, Anderton B, Rosenblum K, Bliss T, et al:: Glycogen synthase kinase-3 inhibition is integral to long-term potentiation. Eur J Neurosci 2007, 25:8I-86.

42. Takahashi M, Tomizawa K, Kato R, Sato K, Uchida T, Fujita SC, Imahori K: Localization and developmental changes of tau protein kinase I/glycogen synthase kinase-3 $\beta$ in rat brain. J Neurochem 1994, 63:245-255.

43. Bhat RV, Budd Haeberlein SL, Avila J: Glycogen synthase kinase 3 : a drug target for CNS therapies. I Neurochem 2004, 89:1313-1317.

44. Plattner F, Angelo M, Giese KP: The roles of cyclin-dependent kinase 5 and glycogen synthase kinase 3 in tau hyperphosphorylation. J Biol Chem 2006, 28 I:25457-25465.

45. Avila J, Lucas J], Perez M, Hernandez F: Role of tau protein in both physiological and pathological conditions. Physiol Rev 2004, 84:36I-384

46. Gould TD, Manji HK: Glycogen synthase kinase-3: a putative molecular target for lithium mimetic drugs. Neuropsychopharmacology 2005, 30: 1223-1237.

47. Ryves WJ, Harwood AJ: Lithium inhibits glycogen synthase kinase- 3 by competition for magnesium. Biochem Biophys Res Commun 200I, 280:720-725.

48. Grimes CA, Jope RS: The multifaceted roles of glycogen synthase kinase $3 \beta$ in cellular signaling. Prog Neurobiol 200I, 65:391-426.

49. Harwood AJ: Lithium and bipolar mood disorder: the inositoldepletion hypothesis revisited. Mol Psychiatry 2005, I 1: I 17-126.

50. Wada A, Yokoo H, Yanagita T, Kobayashi H: Lithium: potential therapeutics against acute brain injuries and chronic neurodegenerative diseases. J Pharmacol Sci 2005, 99:307-32I.

51. Nunes PV, Forlenza OV, Gattaz WF: Lithium and risk for Alzheimer's disease in elderly patients with bipolar disorder. $\mathrm{Br} J$ Psychiatry 2007, 190:359-360.

52. Quintanilla RA, Munoz FJ, Metcalfe MJ, Hitschfeld M, Olivares G, Godoy JA, Inestrosa NC: Trolox and I7 $\beta$-estradiol protect against amyloid $\beta$-peptide neurotoxicity by a mechanism that involves modulation of the Wnt signaling pathway. J Biol Chem 2005, 280:1 I6I5-11625.

53. Alvarez AR, Godoy JA, Mullendorff K, Olivares GH, Bronfman M, Inestrosa NC: Wnt-3a overcomes $\beta$-amyloid toxicity in rat hippocampal neurons. Exp Cell Res 2004, 297: 186-196.

54. Busciglio J, Lorenzo A, Yeh J, Yankner BA: $\beta$-amyloid fibrils induce tau phosphorylation and loss of microtubule binding. Neuron 1995, 14:879-888.

55. Takashima A, Honda T, Yasutake K, Michel G, Murayama O, Murayama M, Ishiguro K, Yamaguchi $\mathrm{H}$ : Activation of tau protein kinase I/glycogen synthase kinase- $3 \beta$ by amyloid $\beta$ peptide (25-35) enhances phosphorylation of tau in hippocampal neurons. Neuroscience research 1998, 31:317-323.

56. Sheldahl LC, Slusarski DC, Pandur P, Miller JR, Kuhl M, Moon RT: Dishevelled activates Ca2+ flux, PKC, and CamKII in vertebrate embryos. J Cell Biol 2003, I61:769-777.

57. De Ferrari GV, Moon RT: The ups and downs of Wnt signaling in prevalent neurological disorders. Oncogene 2006, 25:7545-7553.

58. Esposito G, Scuderi C, Lu J, Savani C, De Filippis D, luvone T, Steardo $L$ Jr, Sheen V, Steardo L: S I OOB induces tau protein hyperphosphorylation via Dickopff-I up-regulation and disrupts the Wnt pathway in human neural stem cells. J Cell Mol Med 2008, I 2:9|4-927.

59. Mudher A, Lovestone S: Alzheimer's disease-do tauists and baptists finally shake hands? Trends Neurosci 2002, 25:22-26.

60. Jones SE, Jomary C, Grist J, Stewart HJ, Neal MJ: Modulated expression of secreted frizzled-related proteins in human retinal degeneration. Neuroreport 2000, I I:3963-3967.

6I. Jones SE, Jomary C, Grist J, Stewart HJ, Neal MJ: Altered expression of secreted frizzled-related protein-2 in retinitis pigmentosa retinas. Invest Ophthalmol Vis Sci 2000, 4I:|297-I30I.

62. Rattner A, Hsieh JC, Smallwood PM, Gilbert DJ, Copeland NG, Jenkins NA, Nathans J: A family of secreted proteins contains homology to the cysteine-rich ligand-binding domain of frizzled receptors. Proc Natl Acad Sci USA I 997, 94:2859-2863.

63. Melkonyan HS, Chang WC, Shapiro JP, Mahadevappa M, Fitzpatrick PA, Kiefer MC, Tomei LD, Umansky SR: SARPs: a family of 
secreted apoptosis-related proteins. Proc Natl Acad Sci USA 1997, 94: | 3636-|364I.

64. Baranski M, Berdougo E, Sandler JS, Darnell DK, Burrus LW: The dynamic expression pattern of frzb-I suggests multiple roles in chick development. Dev Biol 2000, 217:25-41.

65. Strittmatter WJ, Roses AD: Apolipoprotein E and Alzheimer disease. Proc Natl Acad Sci USA 1995, 92:4725-4727.

66. Caruso A, Motolese M, lacovelli L, Caraci F, Copani A, Nicoletti F, Terstappen GC, Gaviraghi G, Caricasole A: Inhibition of the canonical Wnt signaling pathway by apolipoprotein E4 in PCI 2 cells. J Neurochem 2006, 98:364-37I.

67. Daw EW, Payami H, Nemens EJ, Nochlin D, Bird TD, Schellenberg GD, Wijsman EM: The number of trait loci in late-onset Alzheimer disease. Am J Hum Genet 2000, 66: 196-204.

68. de Vrij FM, Fischer DF, van Leeuwen FW, Hol EM: Protein quality control in Alzheimer's disease by the ubiquitin proteasome system. Prog Neurobiol 2004, 74:249-270.

69. Oddo S: The ubiquitin-proteasome system in Alzheimer's disease. J Cell Mol Med 2008, I 2:363-373.

70. Liu C, Li Y, Semenov M, Han C, Baeg GH, Tan Y, Zhang Z, Lin X, He $X$ : Control of $\beta$-catenin phosphorylation/degradation by a dual-kinase mechanism. Cell 2002, 108:837-847.

71. Aberle H, Bauer A, Stappert J, Kispert A, Kemler R: $\beta$-catenin is a target for the ubiquitin-proteasome pathway. EMBO J 1997, 16:3797-3804.

72. Fuenzalida K, Quintanilla R, Ramos P, Piderit D, Fuentealba RA, Martinez G, Inestrosa NC, Bronfman M: Peroxisome proliferatoractivated receptor gamma up-regulates the $\mathrm{Bcl}-2$ anti-apoptotic protein in neurons and induces mitochondrial stabilization and protection against oxidative stress and apoptosis. J Biol Chem 2007, 282:37006-370I5.

73. Farias GG, Valles AS, Colombres M, Godoy JA, Toledo EM, Lukas RJ Barrantes FJ, Inestrosa NC: Wnt-7a induces presynaptic colocalization of $\alpha 7$-nicotinic acetylcholine receptors and adenomatous polyposis coli in hippocampal neurons. J Neurosci 2007, 27:5313-5325.

74. Colombres M, Cerpa W, Velarde V, Nibaldo Cl: Insulin degrading enzyme (IDE) is a target gene of the Wnt signaling pathway (In Prep). FEBS Lett 2008 in press.

75. Arrazola M, Varela-Nallar L, Colombres M, Assar R, Aravena A Maass A, Martínez S, Inestrosa NC: Calcium/calmodulin-dependent protein kinase type IV (CaMKIV) is a target gene of the Wnt/ $\beta$-catenin signaling pathway. EMBO Rep 2008 in press.

76. Inestrosa N, Colombres M, Assar R, Hodar C, Aravena A, Gonzalez M, Maass A, Martinez S: Detection of Novel Wnt Target in the Human Genome. Mol Psychiatry 2008 in press.

77. Li H-L, Wang H-H, Liu S-J, Deng Y-Q, Zhang Y-J, Tian Q, Wang X-C, Chen X-Q, Yang Y, Zhang J-Y, et al.: Phosphorylation of tau antagonizes apoptosis by stabilizing $\beta$-catenin, a mechanism involved in Alzheimer's neurodegeneration. PNAS 2007 104:3591-3596.

78. Wang Y, Thekdi N, Smallwood PM, Macke JP, Nathans J: Frizzled-3 is required for the development of major fiber tracts in the rostral CNS. J Neurosci 2002, 22:8563-8573.

79. Lyuksyutova Al, Lu C-C, Milanesio N, King LA, Guo N, Wang Y, Nathans ], Tessier-Lavigne M, Zou Y: Anterior-Posterior Guidance of Commissural Axons by Wnt-Frizzled Signaling. Science 2003, 302: 1984-1988.

80. Wang Y, Huso D, Cahill H, Ryugo D, Nathans J: Progressive cerebellar, auditory, and esophageal dysfunction caused by targeted disruption of the frizzled-4 gene. J Neurosci 200I, 21:476I-477I.

8I. Zhao C, Aviles C, Abel RA, Almli CR, McQuillen P, Pleasure SJ: Hippocampal and visuospatial learning defects in mice with a deletion of frizzled 9, a gene in the Williams syndrome deletion interval. Development 2005, 132:2917-2927.

82. Wang Y, Guo N, Nathans J: The role of Frizzled3 and Frizzled6 in neural tube closure and in the planar polarity of inner-ear sensory hair cells. J Neurosci 2006, 26:2147-2I56.

83. Sancho $E$, Batlle $E$, Clevers $\mathrm{H}$ : Signaling pathways in intestinal development and cancer. Annu Rev Cell Dev Biol 2004, 20:695-723.

84. Polakis P: The many ways of Wnt in cancer. Curr Opin Genet Dev 2007, I 7:45-5I.

85. Wang HY, Malbon CC: Wnt-frizzled signaling to G-protein-coupled effectors. Cell Mol Life Sci 2004, 61:69-75.
86. Karasawa $\mathrm{T}$, Yokokura H, Kitajewski J, Lombroso PJ: Frizzled-9 is activated by $W n t-2$ and functions in $W n t / \beta$-catenin signaling. J Biol Chem 2002, 277:37479-37486.

87. Caricasole A, Ferraro T, lacovelli L, Barletta E, Caruso A, Melchiorri $D$, Terstappen GC, Nicoletti F: Functional characterization of WNT7A signaling in PCI 2 cells: interaction with A FZD5 $\times$ LRP6 receptor complex and modulation by Dickkopf proteins. J Biol Chem 2003, 278:37024-3703I.

88. Gazit A, Yaniv A, Bafico A, Pramila T, Igarashi M, Kitajewski J, Aaronson SA: Human frizzled I interacts with transforming Wnts to transduce a TCF dependent transcriptional response. Oncogene 1999, 18:5959-5966.

89. Carmon KS, Loose DS: Wnt7a interaction with Fzd5 and detection of signaling activation using a split eGFP. Biochem Biophys Res Commun 2008, 368:285-291.

90. Shimogori T, VanSant J, Paik E, Grove EA: Members of the Wnt, Fz, and Frp gene families expressed in postnatal mouse cerebral cortex. I Comp Neurol 2004, 473:496-5I0.

91. Lein ES, Hawrylycz MJ, Ao N, Ayres M, Bensinger A, Bernard A, Boe AF, Boguski MS, Brockway KS, Byrnes EJ, et al:: Genome-wide atlas of gene expression in the adult mouse brain. Nature 2007, 445: $168-176$.

92. Chacon MA, Varela-Nallar L, Inestrosa NC: Frizzled-I is involved in the neuroprotective effect of Wnt $3 a$ against $A \beta$ oligomers. Journal of Cellular Physiology 2008.

93. Ferreira ST, Vieira MN, De Felice FG: Soluble protein oligomers as emerging toxins in Alzheimer's and other amyloid diseases. IUBMB Life 2007, 59:332-345.

94. Magdesian MH, Nery AA, Martins AH, Juliano MA, Juliano L, Ulrich H, Ferreira ST: Peptide blockers of the inhibition of neuronal nicotinic acetylcholine receptors by amyloid $\beta$. J Biol Chem 2005, 280:31085-31090.

95. Geula C, Mesulam MM: Cholinergic systems and related neuropathological predilection patterns in Alzheimer's disease. Raven Press: New York; 1994

96. Haring R, Gurwitz D, Barg J, Pinkas-Kramarski R, Heldman E, Pittel Z, Wengier A, Meshulam H, Marciano D, Karton Y, et al.: Amyloid precursor protein secretion via muscarinic receptors: reduced desensitization using the MI-selective agonist AFI02B. Biochem Biophys Res Commun 1994, 203:652-658.

97. Genis I, Fisher A, Michaelson DM: Site-specific dephosphorylation of tau of apolipoprotein E-deficient and control mice by MI muscarinic agonist treatment. I Neurochem 1999, 72:206-2I3

98. Xie J, Guo Q, Zhu H, Wooten MW, Mattson MP: Protein kinase C iota protects neural cells against apoptosis induced by amyloid $\beta$-peptide. Brain Res Mol Brain Res 2000, 82:107-II3.

99. Caccamo A, Oddo S, Billings LM, Green KN, Martinez-Coria H, Fisher A, LaFerla FM: MI Receptors Play a Central Role in Modulating AD-like Pathology in Transgenic Mice. Neuron 2006, 49:67I-682.

100. Vlad SC, Miller DR, Kowall NW, Felson DT: Protective effects of NSAIDs on the development of Alzheimer disease. Neurology 2008, 70:1672-1677.

101. Citron M: Strategies for disease modification in Alzheimer's disease. Nat Rev Neurosci 2004, 5:677-685.

102. Morihara T, Chu T, Ubeda O, Beech W, Cole GM: Selective inhibition of $\mathbf{A} \beta \mathbf{4 2}$ production by NSAID R-enantiomers. J Neurochem 2002, 83:1009-1012.

103. Weggen S, Eriksen JL, Das P, Sagi SA, Wang R, Pietrzik CU, Findlay KA, Smith TE, Murphy MP, Bulter T, et al.: A subset of NSAIDs lower amyloidogenic $A \beta 42$ independently of cyclooxygenase activity. Nature 200I, 4I 4:2I 2-2I6.

104. Zhou Y, Su Y, Li B, Liu F, Ryder JW, Wu X, Gonzalez-DeWhitt PA, Gelfanova $\mathrm{V}$, Hale JE, May PC, et al:: Nonsteroidal anti-inflammatory drugs can lower amyloidogenic $A \beta 42$ by inhibiting Rho. Science 2003, 302:1215-1217.

105. Farias GG, Godoy JA, Vazquez MC, Adani R, Meshulam H, Avila J, Amitai G, Inestrosa NC: The anti-inflammatory and cholinesterase inhibitor bifunctional compound IBU-PO protects from $\beta$-amyloid neurotoxicity by acting on Wnt signaling components. Neurobiol Dis 2005, I8:176-183.

106. Miranda S, Opazo C, Larrondo LF, Munoz F], Ruiz F, Leighton F, Inestrosa NC: The role of oxidative stress in the toxicity induced by amyloid $\beta$-peptide in Alzheimer's disease. Prog Neurobiol 2000, 62:633-648. 
107. Cerpa W, Godoy JA, Alafaro I, Farias GG, Metcalfe MJ, Fuentealba R, Bonansco C, Inestrosa NC: WNT-7a modulates the synaptic vesicle cycle and synaptic transmission in hippocampal neurons. J Biol Chem 2008, 283:5918-5927.

108. Behl C, Davis JB, Lesley R, Schubert D: Hydrogen peroxide mediates amyloid $\beta$ protein toxicity. Cell 1994, 77:817-827.

109. Santos MJ, Quintanilla RA, Toro A, Grandy R, Dinamarca MC, Godoy JA, Inestrosa NC: Peroxisomal proliferation protects from $\beta$ amyloid neurodegeneration. J Biol Chem 2005, 280:4I 057-4I 068 .

I10. Willson TM, Wahli W: Peroxisome proliferator-activated receptor agonists. Curr Opin Chem Biol 1997, I:235-24I.

III. Watson GS, Craft S: The role of insulin resistance in the pathogenesis of Alzheimer's disease: implications for treatment. CNS Drugs 2003, 17:27-45.

I 12. Watson GS, Craft S: Insulin resistance, inflammation, and cognition in Alzheimer's Disease: lessons for multiple sclerosis. J Neurol Sci 2006, 245:2I-33.

1 13. Landreth GE, Heneka MT: Anti-inflammatory actions of peroxisome proliferator-activated receptor $\gamma$ agonists in Alzheimer's disease. Neurobiol Aging 200I, 22:937-944.

I14. Feinstein DL: Therapeutic potential of peroxisome proliferator-activated receptor agonists for neurological disease. Diabetes Technol Ther 2003, 5:67-73.

II5. Inestrosa NC, Godoy JA, Quintanilla RA, Koenig CS, Bronfman M: Peroxisome proliferator-activated receptor $\gamma$ is expressed in hippocampal neurons and its activation prevents $\beta$-amyloid neurodegeneration: role of Wnt signaling. Exp Cell Res 2005, 304:91-104.

1 16. Fuentealba RA, Farias G, Scheu J, Bronfman M, Marzolo MP, Inestrosa NC: Signal transduction during amyloid- $\beta$-peptide neurotoxicity: role in Alzheimer disease. Brain Res Brain Res Rev 2004 47:275-289.

117. Camacho IE, Serneels L, Spittaels K, Merchiers P, Dominguez D, De Strooper B: Peroxisome Proliferator-Activated Receptor $\{\gamma\}$ Induces a Clearance Mechanism for the Amyloid- $\{\beta\}$ Peptide. J Neurosci 2004, 24:10908-10917.

I I8. Pedersen WA, Flynn ER: Insulin resistance contributes to aberrant stress responses in the Tg2576 mouse model of Alzheimer's disease. Neurobiol Dis 2004, 17:500-506.

119. Role LW, Berg DK: Nicotinic receptors in the development and modulation of CNS synapses. Neuron 1996, 16:1077-1085.

120. Levin ED, Simon BB: Nicotinic acetylcholine involvement in cognitive function in animals. Psychopharmacology (Berl) 1998, 138:217-230.

121. Vernino S, Amador M, Luetje CW, Patrick J, Dani JA: Calcium modulation and high calcium permeability of neuronal nicotinic acetylcholine receptors. Neuron 1992, 8:127-134.

122. Banerjee C, Nyengaard JR, Wevers A, de Vos RA, Jansen Steur EN, Lindstrom J, Pilz K, Nowacki S, Bloch W, Schroder H: Cellular expression of $\alpha 7$ nicotinic acetylcholine receptor protein in the temporal cortex in Alzheimer's and Parkinson's disease - a stereological approach. Neurobiol Dis 2000, 7:666-672.

123. Kem WR: The brain $\alpha 7$ nicotinic receptor may be an important therapeutic target for the treatment of Alzheimer's disease: studies with DMXBA (GTS-2I). Behav Brain Res 2000, I13:169-181. 政 